\title{
Veljavnost in zanesljivost Lestvice akademske motivacije na vzorcu slovenskih študentov
}

\author{
Melita Puklek Levpušček* in Anja Podlesek \\ Oddelek za psihologijo, Filozofska fakulteta, Univerza v Ljubljani
}

\begin{abstract}
Povzetek: V pričujoči študiji sva ugotavljali konstruktno veljavnost ter zanesljivost Lestvice akademske motivacije, verzije za študente (Academic Motivation Scale, AMS-C 28, Vallerand idr., 1992) ter njeno povezanost s spolom, prepričanostjo v pravilno izbiro študija in poklicnimi cilji. AMS temelji na teoriji samodoločenosti, ki opredeljuje različne vrste motivacije na kontinuumu od amotivacije prek različnih vrst zunanje motivacije do notranje (povsem samodoločujoče) motivacije. Meri torej večdimenzionalni motivacijski konstrukt in vsebuje sedem lestvic. V validacijskem vzorcu je sodelovalo 324 študentov različnih smeri študija na Univerzi v Ljubljani. $\mathrm{Z}$ večskupinsko konfirmatorno faktorsko analizo sva potrdili sprejemljivo prileganje 7-faktorske strukture slovenskim podatkom in mersko invariantnost pripomočka glede na spol. Najvišje so bile korelacije med tremi faktorji notranje motivacije in med tremi faktorji zunanje motivacije. Trenutna prepričanost v pravilno izbiro študija je bila pozitivno povezana $\mathrm{z}$ vsemi tremi faktorji notranje motivacije in identificiranim uravnavanjem ter negativno povezana $\mathrm{z}$ amotivacijo. Ekstrinzični poklicni cilji so se nizko do zmerno visoko povezovali s faktorji zunanje motivacije, intrinzični poklicni cilji pa s tremi faktorji notranje motivacije, identificiranim in introjiciranim uravnavanjem ter negativno z amotivacijo. Študentke so imele na lestvicah želje po obvladovanju, identificiranega in introjiciranega uravnavanja višje dosežke od študentov. Lestvica AMS-C 28 ima ustrezno konstruktno in konvergentno veljavnost ter zanesljivost v slovenskem okolju.
\end{abstract}

Ključne besede: motivacija za študij, vprašalniki, validacija, poklicni cilji, študenti

\section{Validity and reliability of the Academic Motivation Scale in a sample of Slovenian students}

\author{
Melita Puklek Levpušček* and Anja Podlesek \\ Department of Psychology, Faculty of Arts, University of Ljubljana, Slovenia
}

\begin{abstract}
In this study we examined construct validity and reliability of the Academic Motivation Scale, College Version (Academic Motivation Scale, AMS-C 28, Vallerand et al., 1992) and its relationship with gender, certainty of study choice and career goals in Slovenian university students. The theoretical basis of AMS is derived from Self-Determination Theory, which identified different types of motivation on a continuum from amotivation to different types of external motivation and intrinsic (self-determined) motivation. The AMS measures multidimensional motivational construct and contains seven scales. The validation sample consisted of 324 students of various studies at the University of Ljubljana. Multigroup confirmatory factor analysis showed an acceptable fit of the original 7-factor structure on Slovenian data and measurement invariance across gender. The highest were correlations among the three factors of intrinsic motivation and among the three factors of external motivation. Current certainty of study choice was positively associated with all three factors of intrinsic motivation and identified regulation, and negatively correlated with amotivation. Extrinsic career goals had low to moderate positive correlations with factors of external motivation while intrinsic career goals correlated positively with the three factors of intrinsic motivation, identified and introjected regulation, and negatively with amotivation. Female students had higher scores on intrinsic motivation to accomplish, and identified and introjected regulation than male students. In sum, the AMS C-28 showed good construct and convergent validity and reliability in Slovenian university context.
\end{abstract}

Keywords: academic motivation, questionnaires, validation, career goals, university students

\footnotetext{
*Naslov/Address: red. prof. dr. Melita Puklek Levpušček, Oddelek za psihologijo, Filozofska fakulteta, Univerza v Ljubljani, Aškerčeva 2, 1000 Ljubljana, Slovenija, e-pošta: melita.puklek@ff.uni-lj.si
}

Članek je licenciran pod pogoji Creative Commons Attribution 4.0 International licence. (CC-BY licenca). The article is licensed under a Creative Commons Attribution 4.0 International License (CC-BY license). 


\section{Veljavnost in zanesljivost Lestvice akademske motivacije na vzorcu slovenskih študentov}

Lestvica AMS je bila $\mathrm{v}$ francoskem izvirniku objavljena leta 1989 (Vallerand, Blais, Brière in Pelletier, 1989), kmalu zatem pa je bila prevedena tudi $\mathrm{v}$ angleški jezik (Vallerand idr., 1992). Njeno teoretsko ozadje predstavlja teorija samodoločenosti (Ryan in Deci, 2000a), ki opredeljuje notranjo motivacijo kot temelj za posameznikovo avtonomno, samodoločeno vedenje, hkrati pa opredeli različne vrste zunanje motivacije, ko ima neka dejavnost predvsem instrumentalno vrednost (je sredstvo na poti $\mathrm{k}$ cilju) in nastaja na osnovi zunanji pobud, notranjih pritiskov ali posameznikove zaznave dejavnosti kot vredne ali uporabne za dosego cilja. Vrste zunanje motivacije so na motivacijskem kontinuumu različno oddaljene od notranje (povsem samodoločujoče) motivacije glede na stopnjo ponotranjanja oz. integracije zaznane vrednosti naloge in samouravnavanja zahtevanega vedenja. Skrajno nasprotje notranje motivacije predstavlja amotivacija kot stanje pomanjkanja namere za vedenje. Lestvica AMS ima tri različice, ki se uporabljajo na osnovnošolski, srednješolski in študentski populaciji. V študiji se osredotočava na ugotavljanje veljavnosti in zanesljivosti različice za študente (AMS-C 28).

\section{Teorija samodoločenosti}

Na področju raziskovanja učne motivacije se je $\mathrm{v}$ zadnjih desetletjih uveljavila teorija samodoločenosti (angl. selfdetermination theory), v nadaljevanju SDT, avtorjev Richarda M. Ryana in Edwarda L. Decija (Ryan in Deci, 2000a, b). V humanistično usmerjeni teoriji avtorja opisujeta, v kolikšni meri je človekovo vedenje voljno oz. samodoločeno, tj. v kolikšni meri ljudje prevzemamo osebni nadzor nad svojimi dejanji ter jih opravljamo na podlagi lastne izbire. SDT se nadalje ukvarja zraziskovanjem temeljnih potreb, ki usmerjajo posameznikovo dejavnost $\mathrm{v}$ različnih življenjskih kontekstih, prav tako pa izpostavlja pogoje $\mathrm{v}$ socialnih kontekstih, ki omogočajo ali zavirajo zadovoljevanje temeljnih potreb, kot so potreba po povezanosti, avtonomiji in izražanju lastne kompetentnosti.

Deci in Ryan (1985, 2002) sta uvedla taksonomijo vrst motivacije, ki vključuje različne vrste motivacije na kontinuumu posameznikovega uravnavanja lastnih odločitev in vedenja. Na skrajnem levem delu kontinuuma se nahaja amotivacija (angl. amotivation), ki predstavlja odsotnost uravnavanja lastnega vedenja, pomanjkanje namere za vedenje in neizvajanje ali mehanično izvajanje dejavnosti. Posamezniki ne zaznavajo dejavnosti kot vredne, menijo, da so nekompetentni za njeno izvrševanje in ne verjamejo $\mathrm{v}$ uspeh dejavnosti. Na motivacijskem kontinuumu sledijo štiri vrste zunanje motiviranega vedenja: zunanje uravnavanje (angl. external regulation; posameznikovo vedenje je povsem odvisno od zunanjega nadzora in posledic - nagrad in kazni, stopnja samodoločenosti je nizka), introjicirano uravnavanje (angl. introjected regulation; posameznikovo vedenje uravnavajo samonadzor v obliki notranjega pritiska in posledice $\mathrm{v}$ obliki notranjih nagrad (doživljanje ponosa) ali kazni (doživljanje npr. sramu), uravnavanje vedenja je delno ponotranjeno), identificirano uravnavanje (angl. identified regulation; identifikacija $\mathrm{z}$ dejavnostjo, vedenje je še vedno instrumentalne narave, vendar posameznik išče osebni pomen $\mathrm{v}$ neki dejavnosti) ter integrirano uravnavanje (angl. integrated regulation; integracija vrednot, ki jih zavestno sprejmemo, vedenje je samodoločujoče). Na skrajnem desnem delu kontinuuma se nahaja notranja motivacija (angl. intrinsic motivation; posameznik deluje zaradi osebnega zadovoljstva v sami dejavnosti, njegovo vedenje je prototip samodoločenosti). Nekateri avtorji so predpostavili, da se notranja motivacija diferencira $\mathrm{v}$ bolj specifične motive (Deci, 1975; Harter, 1981). Vallerand in sodelavci (Vallerand idr., 1989; Vallerand idr., 1992) tako opredeljujejo tri vrste notranje (intrinzične) motivacije (IM): željo po védenju (angl. IM to know), željo po obvladovanju (angl. IM to accomplish) in željo po doživljanju stimulacije (angl. IM to experience stimulation). Želja po védenju pomeni udejstvovanje $\mathrm{v}$ dejavnosti zaradi užitka in zadovoljstva pri učenju, raziskovanju in odkrivanju novega. Želja po obvladovanju pomeni udejstvovanje $\mathrm{v}$ dejavnosti zaradi užitka in zadovoljstva, ko posameznik skuša presegati sebe ali ustvarjati nekaj novega. Pozornost posameznika ni osredotočena na sam rezultat, ampak na proces, ki vodi $\mathrm{k}$ rezultatu. Koncept želje po obvladovanju je podoben konceptu motivacijskega cilja k obvladovanju (angl. mastery goal), ki izhaja iz teorije motivacijskih ciljev. Želja po doživljanju stimulacije pomeni udejstvovanje $\mathrm{v}$ dejavnosti zaradi pozitivnih občutij, prijetne vznemirjenosti ali estetskega užitka, ki jih posameznik občuti zaradi dejavnosti same. Carbonneau in sodelavci (Carbonneau, Vallerand in Lafrenière, 2012) so v postopkih validacije ugotovili, da gre za tri diferencirane konstrukte, saj med posamezniki obstajajo individualne razlike $\mathrm{v}$ doživljanju določene vrste notranje motivacije; usmerjamo se k tistim dejavnostim, ki zadovoljujejo našo prevladujočo notranjo motivacijo.

\section{Veljavnost in zanesljivost AMS v preteklih študijah}

AMS-C 28 vsebuje začetno vprašanje “Zakaj študiram?" in 28 postavk, ki predstavljajo možne odgovore na to vprašanje. Postavke se razvrščajo v sedem podlestvic, vsako podlestvico predstavljajo štiri postavke. Tri podlestvice opisujejo notranjo motivacijo (željo po védenju, željo po obvladovanju in željo po doživljanju stimulacije), tri lestvice opisujejo zunanjo motivacijo (zunanje uravnavanje, introjicirano uravnavanje, identificirano uravnavanje), ena lestvica pa predstavlja amotivacijo. Lestvice AMS odražajo SDT kontinuum samodoločenosti, pri čemer so različne vrste motivacije razvrščene od najvišje (notranja motivacija, identificirano uravnavanje) do najnižje (zunanje uravnavanje, amotivacija) stopnje samodoločenosti. Tako je predpostavljeno, da so vrste motivacije, ki so bližje na kontinuumu, tudi v večji meri povezane, vrste motivacije, ki vsebujejo višjo stopnjo samodoločenosti, pa so povezane $\mathrm{z}$ bolj prilagojenim delovanjem posameznika v učnem kontekstu, kot so zanimanje za študijske dejavnosti, akademska samopodoba in zaznana študijska učinkovitost (Cokley, Bernard, Cunningham in Motoike, 2001; Guay, Morin, Litalien, Valois in Vallerand, 2015; Vallerand idr., 1989). 
Vallerand in sodelavci so $\mathrm{s}$ postopki eksploratorne faktorske analize (EFA) in konfirmatorne faktorske analize (CFA) v dveh različnih raziskavah potrdili 7-faktorsko strukturo francoske različice vprašalnika (Vallerand idr., 1989). V omenjenih dveh raziskavah pa niso povsem potrdili konvergentne in divergentne veljavnosti vprašalnika. Tako so avtorji ugotovili, da nekatere vrste notranje motivacije bolje korelirajo z introjiciranim kot identificiranim uravnavanjem. Lestvica introjiciranega uravnavanja je tudi pozitivno korelirala z zunanjim kriterijem, in sicer $\mathrm{z}$ interesom za učne dejavnosti. Ugotovili so tudi zmerne do visoke korelacije med tremi vrstami notranje motivacije ( $r$ med 0,52 in 0,64). Testiranje veljavnosti angleške različice AMS na univerzitetnih študentih je pokazalo, da 7-faktorska struktura neustrezno reproducira opazovano kovariančno matriko, vendar so se pokazatelji prileganja modela podatkom zvišali do sprejemljivih vrednosti, ko so avtorji vključili 26 koreliranih rezidualov (Vallerand idr., 1992). Lestvica se je v študijah Valleranda in sodelavcev pokazala kot primerno notranje zanesljiva (povprečen $\alpha=0,80$ in 0,81 ) in zanesljiva $\mathrm{v}$ času (test-retest $\mathrm{v}$ obdobju enega meseca $r=0,75$ in 0,79 ) tako $\mathrm{v}$ francoski kot angleški različici (Vallerand idr., 1989; Vallerand idr., 1992). V naslednjih letih je bilo izvedenih še nekaj študij veljavnosti angleške in francoske različice. Konstruktna veljavnost AMS se je v nekaterih raziskavah pokazala kot primerna (Cokley idr., 2001; Fairchild, Horsta, Finneya in Barron, 2005), v nekaterih raziskavah pa so določeni indeksi prileganja bili pod optimalno mejo (Blanchard, Virgnaud, Lallemand, Donson in Wach, 1997). V izobraževalnem kontekstu se je, v nasprotju z izhodišči SDT teorije, v študijah pokazalo, da introjicirano uravnavanje kot razlog za študij konsistentno pozitivno korelira $\mathrm{z}$ akademskim interesom (Blanchard idr., 1997; Vallerand idr., 1993), cilji obvladovanja (Fairchild idr., 2005), usmerjenostjo v nalogo, pozornostjo in pozitivnimi čustvi do učenja (Vallerand idr., 1993) ter zaznano akademsko kompetentnostjo (Guay idr., 2015). Podobno kot v prvi študiji veljavnosti Valleranda (Vallerand idr., 1989) avtorji tudi v naslednjih raziskavah veljavnosti ugotavljajo, da so nekatere vrste notranje motivacije (želja po obvladovanju in doživljanju stimulacije) bolj povezane $\mathrm{z}$ introjiciranim kot identificiranim uravnavanjem (Blanchard idr., 1997; Fairchild idr., 2005; Vallerand idr., 1993), čeprav se slednja vrsta motivacije pojmuje kot bolj samodoločujoča. Omenjene študije tudi konsistentno ugotavljajo zmerne do visoke korelacije med tremi vrstami notranje motivacije $(r$ nad 0,50 do 0,87$)$.

Guay in sodelavci (Guay idr., 2015) v eni zadnjih študij veljavnosti AMS ugotavljajo, da se faktorska struktura AMS bolje prilega podatkom, ko uporabimo postopek eksploratornega strukturnega modeliranja, kot pa če uporabimo konfirmatorno faktorsko analizo. Prav tako so $\mathrm{z}$ omenjenim postopkom na vzorcu francosko govorečih kanadskih univerzitetnih študentov potrdili invariantnost faktorske strukture med spoloma.

\section{Cilji in hipoteze}

$\mathrm{V}$ raziskavi sva želeli preveriti konstruktno veljavnost lestvice AMS-C 28 na vzorcu slovenskih univerzitetnih študentov. Pri tem naju je zanimalo, ali lahko potrdiva originalno predpostavljeno 7-faktorsko strukturo vprašalnika. Preverili sva mersko invariantnost lestvice, in sicer glede na spol. Zanimalo naju je tudi, ali je lestvica primerno zanesljiva oz. notranje konsistentna.

Konvergentno veljavnost lestvice AMS-C 28 sva ugotavljali v pričujoči študiji s korelacijami med posameznimi lestvicami AMS ter korelacijami lestvic AMS z intrinzičnimi in ekstrinzičnimi poklicnimi cilji ter prepričanostjo študentov v pravi izbor svojega študija. Predpostavljali sva, da, skladno z izhodišči SDT teorije, med posameznimi vrstami motivacije prihaja do korelacij; korelacije med vrstami notranje motivacije bodo višje kot korelacije med vrstami notranje in vrstami zunanje motivacije; korelacije med vrstami zunanje motivacije (zunanje in introjicirano uravnavanje) bodo višje kot korelacije med vrstami notranje in zunanje motivacije. Predpostavljali sva tudi negativno korelacijo med vrstami notranje motivacije in amotivacijo. Nadalje sva predpostavljali pozitivno povezanost vrst notranje motivacije $\mathrm{z}$ intrinzičnimi poklicnimi cilji ter prepričanostjo $\mathrm{v}$ pravilno izbiro svojega študija, pozitivno povezanost vrst zunanje motivacije in ekstrinzičnih poklicnih ciljev ter negativno korelacijo med amotivacijo ter intrinzičnimi poklicnimi cilji in prepričanostjo v pravilno izbiro svojega študija.

$\mathrm{V}$ pričujoči študiji sva preverjali tudi razlike $\mathrm{v}$ lestvicah AMS-C 28 po spolu. Predpostavljali sva razlike med študentkami in študenti $\mathrm{v}$ doživljanju vidikov notranje in zunanje motivacije. $\mathrm{V}$ raziskavah ugotavljajo, da imajo študentke $v$ večji meri izražene nekatere vidike notranje motivacije ter višje stopnje introjiciranega in identificiranega uravnavanja (Guay idr., 2015; Vallerand idr., 1989; Vallerand idr., 1992). Primerjava dosežkov po spolu v zunanjem uravnavanju in amotivaciji kaže različne rezultate; v nekaterih študijah avtorji ugotavljajo, da imajo študentje višjo stopnjo zunanjega uravnavanja in amotivacije (Guay idr., 2015; Vallerand idr., 1989), v nekaterih študijah pa ugotavljajo, da $\mathrm{v}$ omenjenih vrstah motivacije po spolu ni razlik (Vallerand idr., 1992).

\section{Metoda}

\section{Udeleženci}

V priložnostni vzorec je bilo vključenih 336 študentov Univerze v Ljubljani. V validacijski vzorec sva vključili 324 posameznikov, od tega 156 (48 \%) žensk in 168 (52\%) moških, ki so odgovorili na vse postavke Lestvice akademske motivacije: 148 (46\%) študentov družboslovja in humanistike, 169 (52 \%) študentov naravoslovja ali tehničnih študijev, 7 (2\%) vključenih študentov pa ni podalo podatka o smeri študija. Študenti so bili stari med 19 in 30 let $(M=22,3, S D$ $=2,1)$. Večina $(n=286 ; 88 \%)$ študentov je poročala, da samo študirajo, ostali $(n=38 ; 12 \%)$ pa, da tudi občasno delajo. Nekaj več kot tretjina študentov $(n=112 ; 35 \%)$ je v času izvedbe raziskave živela s starši, 174 (54\%) jih je živela s partnerjem pri starših ali delno pri starših, delno sami ali delno s partnerjem (npr. v študentskem domu, najemniškem stanovanju ...), 36 (11,1\%) pa jih je živelo samih ali s partnerji (odseljeni od doma); 2 udeleženca o tem nista podala podatka. Nekaj manj kot polovica udeležencev je poročala, da so v intimnem razmerju (42,7\%). 


\section{Pripomočki}

Študenti so najprej poročali o starosti, spolu, bivanju, vrsti študija, zaposlitvenem in partnerskem statusu. Nato so odgovorili na dve vprašanji: "V kolikšni meri ste bili pred študijem prepričani, da je študij, ki ga opravljate oz. ste ga zaključili, prava izbira?" ter "V kolikšni meri ste trenutno prepričani, da je bil študij, ki ga opravljate oz. ste ga zaključili, prava izbira?". Odgovarjali so na 5-stopenjski lestvici (1 - Sploh nisem bil/a prepričan/a oz. Sploh nisem prepričan/a do 5 - Popolnoma sem bil/a prepričan/a oz. Popolnoma sem prepričan/a). V nadaljevanju so izpolnjevali dva vprašalnika: Lestvico akademske motivacije (Vallerand idr., 1992) in Lestvico poklicnih ciljev (Seibert, Kraimer, Holtom in Pierotti, 2013).

Lestvicaakademskemotivacije(AMS, Vallerandidr., 1992) je opisana v uvodu članka. AMS predstavlja večdimenzionalni motivacijski konstrukt, kot ga opredeljujeta avtorja Deci in Ryan v SDT teoriji (Ryan in Deci, 2000a). Različica AMS-C 28 vsebuje izhodiščno vprašanje “Zakaj študiram?", kateremu sledi 28 postavk, ki tvorijo 7 podlestvic (vsaka s 4 postavkami). Udeleženci odgovarjajo na postavke na 7-stopenjski lestvici (1 - sploh ne velja zame do 7 - popolnoma velja zame). V tabeli 1 so predstavljene vse postavke lestvice, ključ za vrednotenje posameznih podlestvic pa je naslednji: Amotivacija: 5, 12, 19 in 26; Zunanje uravnavanje: 1, 12, 19, 26; Introjicirano uravnavanje: $7,14,21,28$; Identificirano uravnavanje: 3,10 , 17, 24; Notranja motivacija - Želja po védenju: 2, 9, 16, 23; Notranja motivacija - Želja po obvladovanju: 6, 13, 20 27; Notranja motivacija - Želja po doživljanju stimulacije: 4, 11, 18, 25. Čeprav Deci in Ryan (1985) med vrstami zunanje motivacije navajata tudi integrirano uravnavanje, ta vrsta motivacije ni vključena v AMS. Kot razlog Vallerand idr. (1992) navajajo dejstvo, da se v poskusnih fazah ugotavljanja veljavnosti lestvice AMS integrirano uravnavanje ni izkazalo kot neodvisno področje razlogov za študij, ampak so se postavke tega področja $\mathrm{v}$ faktorskih analizah združevale $\mathrm{s}$ postavkami identificiranega uravnavanja.

Rezultati študij veljavnosti, v katerih so avtorji preverjali zanesljivost ter konstruktno, konvergentno in diskriminativno veljavnost angleške in francoske različice AMS, so predstavljeni v uvodu.

Lestvica poklicnih ciljev (Career Goals Scale, CGS, Seibert idr., 2013) vsebuje 10 postavk, ki merijo intrinzične in ekstrinzične poklicne cilje. Intrinzični poklicni cilji (5 postavk; primer: Pomembno mi je, da mi poklic ponuja možnosti za zanimivo delo), ekstrinzični poklicni cilji (5 postavk; primer: Želim poklic, s katerim lahko dosežem visok družbeni položaj). Udeleženci odgovarjajo na 5stopenjski lestvici (1 - sploh se ne strinjam do 5 - popolnoma se strinjam). V študiji M. Puklek Levpušček, V. Rauch in Komidarja (v recenziji) se je CGS izkazala kot primerno notranje zanesljiva ( $\alpha=0,78$ za obe lestvici). V pričujoči študiji sva s konfirmatorno faktorsko analizo (z metodo največjega verjetja in robustnim ocenjevanjem standardnih napak parametrov, t. i. metodo MLR) na istem vzorcu (pri čemer so 5 udeležencem manjkali podatki na teh spremenljivkah) preverili strukturo vprašalnika in ugotovili, da se dvofaktorski model ustrezno prilega podatkom, $\chi^{2}(34$,
$N=319)=79,63, p<, 001, \mathrm{CFI}=0,94, \mathrm{TLI}=0,92, \mathrm{RMSEA}$ $=0,064, p(0,046 \leq \mathrm{RMSEA} \leq 0,083)=0,90, \mathrm{SRMR}=0,047$. Standardizirane nasičenosti [in njihovi 95-odstotni intervali zaupanja v oglatih oklepajih] postavk 1-5 s prvim faktorjem, tj. faktorjem Ekstrinzični cilji, so bile 0,49 [0,37-0,60], $0,68[0,59-0,76], 0,90[0,84-0,95], 0,80[0,73-0,86]$ in 0,38 $[0,27-0,50]$, postavk $6-10 \mathrm{z}$ drugim faktorjem, faktorjem Intrinzični cilji, pa $0,66[0,57-0,76], 0,63[0,52-0,74], 0,67$ $[0,57-0,77], 0,78[0,70-0,86]$ in $0,48[0,36-0,60]$. Faktorja nista statistično značilno korelirala, $r=0,10, p=0,166$. Lestvica se je tudi v pričujoči študiji izkazala kot notranje zanesljiva: $\alpha=0,78$ za intrinzične poklicne cilje in $\alpha=0,78 \mathrm{za}$ ekstrinzične poklicne cilje.

\section{Postopek}

Postavke lestvice AMS-28 so bile prevedene v slovenščino popostopkuvzvratnegaprevoda. Najprejstadvestrokovnjakinji $\mathrm{s}$ psihološkega področja prevedli postavke iz angleščine $\mathrm{v}$ slovenščino in s soglasjem uskladili svoja prevoda. Nato je univerzitetna diplomirana prevajalka prevedla slovenske postavke nazaj $\mathrm{v}$ angleščino. Na koncu sta prva avtorica članka in študentka drugostopenjskega programa psihologije Victoria Rauch primerjali originalne postavke v angleškem jeziku in postavke, kot jih je $\mathrm{v}$ angleščino prevedla prevajalka. Slovenski prevod postavk sta ocenili kot ustrezen.

Podatki so bili zbrani na različnih fakultetah Univerze v Ljubljani v zimskem semestru v študijskem letu 2014/15. Študenti Filozofske fakultete v Ljubljani $(n=90)$ so izpolnjevali vprašalnike $\mathrm{v}$ papirni obliki na uvodnem predavanju predmeta Psihologija za učitelje. Ostale študente je posamezno kontaktirala podiplomska študentka, sodelavka pri raziskavi, na njihovih fakultetah ali v študentskih domovih. Tudi ti študentje so izpolnjevali vprašalnike v papirni obliki. Izpolnjevanje vprašalnikov je trajalo približno 10-15 minut.

\section{Rezultati z razpravo}

Najprej sva izvedli analizo postavk. Opisne statistike in indeksi diskriminativnosti postavk s popravkom za prekrivanje so prikazane v tabeli 1. Vidimo lahko, da je večina postavk visoko korelirala z dosežkom na podlestvici, kateri postavka pripada. Prav tako je opazno, da so porazdelitve odgovorov pri postavkah odstopale od normalne.

Da bi preverili, ali 7-faktorska struktura ustreza tudi slovenskim podatkom in je priredba mersko invariantna glede na spol (torej $\mathrm{z}$ njo pri obeh spolih lahko na enak način in enako dobro merimo akademsko motivacijo), sva s statističnim programom Mplus 6.12 (Muthén in Muthén, 1998-2010) izvedli večskupinsko konfirmatorno faktorsko analizo. Odgovore na postavke sva obravnavali kot zvezne spremenljivke. Ker so odstopali od normalne porazdelitve (glej tabelo 1), sva uporabili algoritem največjega verjetja $\mathrm{z}$ robustno oceno standardnih napak parametrov. Mejo statistične značilnosti rezultatov sva postavili pri 5-odstotni ravni alfa napake. Rezultati analize so prikazani v tabeli 2.

Konfiguralni model, tj. model, ki predvideva enakost faktorske strukture pri obeh spolih, ne pa tudi enakosti regresijskih parametrov, skaterimina osnovivrednosti faktorja 
Tabela 1. Opisna statistika odgovorov pri posameznih postavkah lestvice AMS-C 28

\begin{tabular}{ll}
\hline Št. & Postavka \\
\hline 1 & Ker s srednješolsko izobrazbo ne bi mogel/mogla najti dobro plačane
\end{tabular}
službe.

2 Ker občutim užitek in zadovoljstvo, ko se učim novih stvari.

3 Ker mislim, da mi bo univerzitetna izobrazba pomagala, da se bolje pripravim na izbrano karierno pot.

4 Zaradi prijetnih občutkov, ki jih doživljam, ko o svojih idejah razpravljam $\mathrm{z}$ drugimi.

5 Odkrito povedano, ne vem: imam občutek, da na fakulteti zapravljam čas.

6 Zaradi zadovoljstva, ki ga občutim, ko pri študiju prekosim samega/samo sebe.

7 Da si dokažem, da sem sposoben/-na dokončati fakulteto.

8 Da si bom kasneje pridobil/-a bolj ugledno službo.

9 Zaradi zadovoljstva, ki ga doživim ob odkrivanju novih, dotlej neznanih stvari.

10 Ker me bo študij na fakulteti navsezadnje usposobil za vstop na trg dela na področju, ki mi je všeč.

11 Zaradi zadovoljstva, ki ga občutim ob prebiranju zanimive strokovne literature.

12 Nekoč sem imel/-a dobre razloge, zakaj študirati na fakulteti; vendar se sedaj sprašujem, ali naj nadaljujem.

13 Zaradi zadovoljstva, ki ga občutim, ko prekosim samega/samo sebe pri katerem od osebnih dosežkov.

14 Zaradi dejstva, da se počutim pomembno, ko sem uspešen/-na na fakulteti.

15 Ker želim kasneje dobro živeti.

16 Zaradi zadovoljstva, ki ga občutim ob širjenju znanja o vsebinah, ki me zanimajo.

17 Ker mi bo študij na fakulteti pomagal pri boljšem odločanju glede moje kariere.

18 Zaradi zadovoljstva, ki ga občutim, ko sem povsem zatopljen/-a v vsebine, o katerih pišejo določeni avtorji.

19 Ne razumem, zakaj študiram, in, odkrito povedano, za študij mi ne bi moglo biti bolj vseeno.

20 Zaradi zadovoljstva, ki ga občutim, ko opravljam težke študijske naloge.

21 Da si dokažem, da sem inteligentna oseba.

22 Z namenom, da bom kasneje imel/-a boljšo plačo.

23 Ker mi študij omogoča, da nadaljujem $z$ učenjem o številnih stvareh, ki me zanimajo.

24 Ker verjamem, da bom zaradi dodatnih let izobraževanja bolje usposobljen/-a zaposlen/zaposlena.

25 Zaradi doživljanja »omamnega« občutka, ko berem o različnih zanimivih temah.

26 Ne vem; ne razumem, kaj počnem na fakulteti.

27 Ker mi študij omogoča izkusiti osebno zadovoljstvo, ko si prizadevam za odličnost pri učenju.

28 Ker si želim dokazati, da sem lahko pri učenju uspešen/-na.

$\begin{array}{rrrrrr}M & S D & M d n & \gamma_{1} & \gamma_{2} & \\ 4,93 & 1,91 & 5,37 & -0,76 & -0,57 & 0,48^{*}\end{array}$

$\begin{array}{llllll}5,34 & 1,43 & 5,52 & -0,90 & 0,62 & 0,67\end{array}$

$\begin{array}{llllll}4,72 & 1,57 & 4,83 & -0,45 & -0,43 & 0,57\end{array}$

$2,41 \quad 1,61 \quad 1,94 \quad 1,15 \quad 0,50 \quad 0,78$

$\begin{array}{llllll}4,70 & 1,73 & 4,93 & -0,47 & -0,71 & 0,75\end{array}$

$\begin{array}{llllll}4,72 & 1,98 & 5,14 & -0,61 & -0,82 & 0,65\end{array}$

$\begin{array}{llllll}5,22 & 1,76 & 5,63 & -0,94 & -0,09 & 0,72\end{array}$

$\begin{array}{llllll}5,23 & 1,45 & 5,39 & -0,60 & -0,33 & 0,75\end{array}$

$\begin{array}{llllll}5,53 & 1,44 & 5,79 & -0,91 & 0,29 & 0,60\end{array}$

$\begin{array}{llllll}4,24 & 1,66 & 4,29 & -0,09 & -0,81 & 0,60\end{array}$

$2,76 \quad 1,90 \quad 2,14 \quad 0,85 \quad-0,55 \quad 0,61$

$\begin{array}{llllll}4,83 & 1,74 & 5,10 & -0,59 & -0,57 & 0,76\end{array}$

$\begin{array}{llllll}4,32 & 1,86 & 4,49 & -0,24 & -1,06 & 0,64\end{array}$

$\begin{array}{llllll}5,74 & 1,43 & 6,09 & -1,31 & 1,37 & 0,67\end{array}$

$\begin{array}{llllll}5,40 & 1,47 & 5,65 & -0,95 & 0,36 & 0,64\end{array}$

$\begin{array}{llllll}5,10 & 1,51 & 5,34 & -0,74 & -0,11 & 0,58\end{array}$

$\begin{array}{llllll}4,20 & 1,75 & 4,20 & -0,04 & -0,94 & 0,76\end{array}$

$\begin{array}{llllll}1,92 & 1,55 & 1,49 & 1,91 & 2,78 & 0,78\end{array}$

$\begin{array}{llllll}4,06 & 1,70 & 4,10 & -0,05 & -0,85 & 0,65\end{array}$

$\begin{array}{llllll}4,33 & 1,96 & 4,56 & -0,28 & -1,16 & 0,70\end{array}$

$\begin{array}{llllll}5,09 & 1,67 & 5,39 & -0,83 & -0,09 & 0,76\end{array}$

$\begin{array}{llllll}5,40 & 1,41 & 5,60 & -0,79 & 0,04 & 0,64\end{array}$

$\begin{array}{llllll}5,30 & 1,58 & 5,58 & -0,90 & 0,10 & 0,62\end{array}$

$\begin{array}{llllll}3,68 & 1,71 & 3,70 & 0,11 & -0,90 & 0,69\end{array}$

$\begin{array}{llllll}1,81 & 1,48 & 1,42 & 2,06 & 3,48 & 0,76\end{array}$

$\begin{array}{llllll}4,35 & 1,73 & 4,45 & -0,23 & -0,75 & 0,69\end{array}$

$\begin{array}{llllll}4,90 & 1,78 & 5,23 & -0,62 & -0,63 & 0,75\end{array}$

Opomba: Oznaka $\gamma_{1}$ predstavlja Pearsonov koeficient asimetrije, standardna napaka zanj je znašala 0,14. Oznaka $\gamma_{2}$ predstavlja Pearsonov koeficient presežka sploščenosti, standardna napaka zanj je znašala 0,27 . Oznaka $r^{*}$ predstavlja korelacijo postavke z vsoto preostalih postavk, ki sestavljajo posamezno lestvico (indeks diskriminativnosti s popravkom za prekrivanje).

${ }^{a}$ Postavka 1 je bila edina od vseh, pri kateri bi bil Cronbachov koeficient alfa za lestvico višji, če bi postavko izločili (alfa bi se zvišala na $0,86)$. 
Tabela 2. Primerjava modelov za preverjanje merske invariantnosti glede na spol

\begin{tabular}{|c|c|c|c|}
\hline Primerjava modelov & $\Delta \chi^{2}$ & $\Delta d f$ & $p$ \\
\hline Konfiguralni vs. ničelni & 1229,97 & 658 & $<, 001$ \\
\hline Metrični vs. konfiguralni & 14,67 & 21 & ,839 \\
\hline Skalarni vs. konfiguralni & 49,94 & 42 & 187 \\
\hline Skalarni vs. metrični & 36,32 & 21 & 020 \\
\hline Skalarni $2^{\text {a }}$ vs. metrični & 24,11 & 20 & ,238 \\
\hline \multicolumn{4}{|c|}{ Razlike med spoloma - primerjava s skalarnim modelom 2} \\
\hline Hipoteza 0 (vse lestvice skupaj) & 21,75 & 7 & 003 \\
\hline Hipoteza 1 (Želja po védenju) & 1,69 & 1 & ,194 \\
\hline Hipoteza 2 (Želja po obvladovanju) & 7,43 & 1 &, 006 \\
\hline Hipoteza 3 (Želja po doživljanju stimulacije) & 1,07 & 1 & ,300 \\
\hline Hipoteza 4 (Identificirano uravnavanje) & 12,91 & 1 & $<, 000$ \\
\hline Hipoteza 5 (Introjicirano uravnavanje) & 6,63 & 1 &, 010 \\
\hline Hipoteza 6 (Zunanje uravnavanje) & 0,23 & 1 & ,632 \\
\hline Hipoteza 7 (Amotivacija) & 3,12 & 1 &, 077 \\
\hline
\end{tabular}

${ }^{a}$ Skalarni 2: V tem modelu sva sprostili pogoj enakosti povprečij/presečišč postavke 20.

napovedujemo dejanski odgovor na postavki (tj., povprečja in nasičenosti postavke $\mathrm{z}$ relevantnim faktorjem), je v primerjavi z modelom brez povezanosti med spremenljivkami statistično značilno izboljšal pojasnjevanje kovariančne matrike $\left(\chi^{2}[658]\right.$ $=1229,97, p<, 001, \chi^{2} / d f=1,87 ; \mathrm{CFI}=0,87, \mathrm{TLI}=0,85$, RMSEA $=, 073, p<, 001, p[, 067 \leq \mathrm{RMSEA} \leq, 080]=, 90 ;$ SRMR $=$ ,072). Različni indeksi prileganja so kazali (glede na Hooper, Coughlan in Mullen, 2008; Hu in Bentler, 1999) sprejemljivo prileganje konfiguralnega modela podatkom. Zaključili sva, da se postavke razvrščajo po posameznih faktorjih na enak način, kot so ugotovili Vallerand idr. (1992).

V metričnem modelu sva predpostavili, da so nasičenosti postavk s posameznimi faktorji pri obeh spolih enake. Model se je zadovoljivo prilegal podatkom, $\chi^{2}[679]=1244,43, p<$ $, 001, \chi^{2} / d f=1,83$; prispevek moških $\mathrm{k} \chi^{2}=602,91$, prispevek žensk k $\chi^{2}=641,52 ; \mathrm{CFI}=, 87, \mathrm{TLI}=0,85$; $\mathrm{RMSEA}=, 072, p<$ $, 001, p[, 065 \leq \mathrm{RMSEA} \leq, 078]=, 90 ; \mathrm{SRMR}=, 074$. Metrični model $\mathrm{v}$ primerjavi $\mathrm{s}$ konfiguralnim ni statistično značilno poslabšal vrednosti $\chi^{2}$ (glej tabelo 2), zato sva zaključili, da je slovenska priredba AMS-C metrično invariantna, kar pomeni, da lahko trdimo, da so nasičenosti postavk enake pri obeh spolih.

V skalarnem modelu sva pri študentkah in študentih poleg nasičenosti izenačili tudi povprečja odgovorov na postavke (oz. presečišča $\mathrm{v}$ enačbah za napovedovanje manifestnih spremenljivk na osnovi latentnih faktorjev). Prileganje modela je bilo zadovoljivo, $\chi^{2}[700]=1280,93, p<, 001, \chi^{2} / d f=$ 1,83; prispevek moških $\mathrm{k} \chi^{2}=623,03$, prispevek žensk k $\chi^{2}=$ 657,$90 ; \mathrm{CFI}=, 87, \mathrm{TLI}=0,85 ; \mathrm{RMSEA}=, 072, p<, 001, p[, 065$ $\leq \mathrm{RMSEA} \leq, 078]=, 90 ;$ SRMR $=, 074$. Vrednost statistike $\chi^{2}$ je bila pri skalarnem modelu statistično značilno višja kot pri metričnem modelu (tabela 2), na osnovi česar sva zaključili, da izenačevanje povprečij pri spolih v modelu, ki pojasnjuje odgovore na postavke, ni ustrezno. Pregled modifikacijskih indeksov je pokazal, da je k zvišanju vrednosti modelnega $\chi^{2}$ visoko prispevalo izenačevanje povprečij pri postavki 20, pri drugih postavkah pa le malo. Zato sva oblikovali še en skalarni model (v tabeli 2 je označen kot skalarni 2), v katerem so bila pri študentkah in študentih izenačena vsa nasičenja postavk s faktorji in vsa povprečja, razen povprečje pri postavki 20. Ko sva sprostili pogoj enakosti povprečij pri tej postavki, se prileganje modela ni več statistično značilno razlikovalo od prileganja metričnega modela. Indeksi prileganja so pokazali sprejemljivo prileganje takega skalarnega modela slovenskim podatkom: $\chi^{2}[699]=1269,58, p<, 001, \chi^{2} / d f=1,82$; prispevek moških k $\chi^{2}=616,15$, prispevek žensk k $\chi^{2}=653,39$; CFI $=$ $, 87, \mathrm{TLI}=0,86$; RMSEA $=, 071, p<, 001, p[, 065 \leq \mathrm{RMSEA}$ $\leq, 077]=, 90 ;$ SRMR $=, 074$. Zaključujeva, da za slovensko priredbo AMS-C 28 velja delna skalarna invariantnost glede na spol (polna skalarna invariantnost je kršena le z razlikami v presečiščih pri postavki 20). Ob upoštevanju kompleksnosti končnega, 7-faktorskega modela, meniva, da ta odraža ustrezno konstruktno veljavnost vprašalnika AMS-C 28 na vzorcu slovenskih študentov. Podobno so v svojih študijah veljavnosti ugotovili tudi avtorji lestvice ter ostali raziskovalci (npr. Cokley idr., 2001; Fairchild idr., 2005; Vallerand idr., 1989; Vallerand idr., 1992).

$\mathrm{V}$ tabeli 3 prikazujeva ocene parametrov (nasičenosti postavk) za 7-faktorsko rešitev, ki ustreza strukturi originalne lestvice Valleranda idr. (1992) in velja za oba spola.

Delna skalarna invariantnost AMS-C 28 glede na spol pomeni, da pri študentkah in študentih lahko uporabimo enaka merska modela, edino pri postavki 20 bi morali presečišče oceniti ločeno za vsak spol (za študente je nestandardizirano presečišče znašalo 4,12, za študentke pa $3,60)$. Težko je razložiti, kaj so poleg spolnih razlik v latentni spremenljivki, ki so zajete $\mathrm{v}$ razlikah med dosežkoma obeh spolov na faktorju, ki nasiča to postavko, še razlogi za to, da študentke na to postavko odgovarjajo drugače kot študenti. Gre za postavko, ki na vprašanje »Zakaj študiram?« ponudi odgovor: »Zaradi zadovoljstva, ki ga občutim, ko opravljam težke študijske naloge«. Razlike v presečiščih bi morda lahko odražale razlike med študentkami in študenti $\mathrm{v}$ zaznavi in pojmovanju tega, kaj so »težke študijske naloge«, ali pa v 
Tabela 3. Standardizirani koeficienti nasičenosti postavks faktorji [in njihovi 95-odstotni intervali zaupanja v oglatih oklepajih] in nepojasnjene variance postavk

\begin{tabular}{|c|c|c|c|c|c|c|c|c|}
\hline Št. & $\mathrm{F} 1$ & $\mathrm{~F} 2$ & F3 & $\mathrm{F} 4$ & F5 & F6 & F7 & $e$ \\
\hline 2 &, $74[, 65-, 82]$ & & & & & & & ,46 \\
\hline 9 &, $82[, 75-, 89]$ & & & & & & & ,33 \\
\hline 16 &, $73[, 65-, 81]$ & & & & & & & ,47 \\
\hline 23 &, $72[, 63-, 81]$ & & & & & & & ,48 \\
\hline 6 & &, $80[, 73-, 88]$ & & & & & & ,36 \\
\hline 13 & &, $83[, 78-, 89]$ & & & & & & 31 \\
\hline 20 & &, $72[, 62-, 81]$ & & & & & & ,49 \\
\hline 27 & &, $77[, 70-, 84]$ & & & & & & ,41 \\
\hline 4 & & &, $66[, 58-, 75]$ & & & & & ,56 \\
\hline 11 & & & ,68 [,59-,77] & & & & &, 54 \\
\hline 18 & & &, $84[, 77-, 91]$ & & & & &, 30 \\
\hline 25 & & &, $78[, 70-, 85]$ & & & & & ,40 \\
\hline 3 & & & &, $65[, 54-, 76]$ & & & & ,58 \\
\hline 10 & & & &, $63[, 50-, 76]$ & & & & 60 \\
\hline 17 & & & & $69[, 58-, 80]$ & & & &, 52 \\
\hline 24 & & & &, $72[, 62-, 83]$ & & & & , 48 \\
\hline 7 & & & & &, $73[, 64-, 82]$ & & & ,47 \\
\hline 14 & & & & &, $73[, 64-, 82]$ & & & ,47 \\
\hline 21 & & & & &, $75[, 66-, 83]$ & & &, 44 \\
\hline 28 & & & & &, $78[, 69-, 86]$ & & & ,40 \\
\hline 1 & & & & & &, $56[, 42-, 69]$ & & ,69 \\
\hline 8 & & & & & &, $88[, 81-, 95]$ & &, 23 \\
\hline 15 & & & & & &, $72[, 61-, 82]$ & & ,49 \\
\hline 22 & & & & & &, $86[, 80-, 92]$ & & ,26 \\
\hline 5 & & & & & & &, $77[, 69-, 86]$ & ,40 \\
\hline 12 & & & & & & &, $62[, 49-, 75]$ & ,62 \\
\hline 19 & & & & & & &, $84[, 76-, 92]$ &, 30 \\
\hline 26 & & & & & & &, $83[, 74-, 93]$ &, 31 \\
\hline
\end{tabular}

Opombe: $\breve{\text { Št. }}$ = zaporedna številka postavke AMS-C, F1 = Notranja motivacija - Želja po védenju, F2 = Notranja motivacija - Želja po obvladovanju, F3 = Notranja motivacija - Želja po doživljanju stimulacije; F4 = Identificirano uravnavanje, F5 = Introjicirano uravnavanje, $\mathrm{F} 6=$ Zunanje uravnavanje, $\mathrm{F} 7=$ Amotivacija, $e=$ delež nepojasnjene variance postavk. Vsi koeficienti so bili statistično značilno različni od $0, p<, 001$.

tem, da študentke in študenti pri opravljanju težkih študijskih nalog občutijo različno stopnjo zadovoljstva, in to vpliva na odgovor pri postavki, s katero sicer ne želimo meriti, kakšno zadovoljstvo občutijo udeleženci, temveč, v kolikšni meri to zadovoljstvo prispeva k motiviranosti za študij.

Notranjo zanesljivost sedmih faktorjev sva izračunali $\mathrm{Z}$ uporabo funkcije guttman $\mathrm{V}$ paketu $\mathrm{R}$. Vrednosti Cronbachovega koeficienta alfa in ocenjene glb (tj., najvišje spodnje meje zanesljivosti, osnovane na komunalitetah; glej Revelle, b. d., in npr. Ten Berge in Sočan, 2004) na standardiziranih odgovornih lestvicah so bile ustrezne: za lestvico Želja po védenju je bila $\alpha=0,83(\mathrm{glb}=0,83)$, za lestvico Želja po obvladovanju $\alpha=0,86(\mathrm{glb}=0,92)$, za lestvico Želja po doživljanju stimulacije $\alpha=0,82(\mathrm{glb}=0,84)$, za lestvico Identificirano uravnavanje $\alpha=0,78(\mathrm{glb}=0,78)$, za lestvico Introjicirano uravnavanje $\alpha=0,85(\mathrm{glb}=0,85)$, za lestvico Zunanje uravnavanje $\alpha=0,81(\mathrm{glb}=0,83)$ in za lestvico Amotivacija $\alpha=0,85$ ( $\mathrm{glb}=0,86)$.

Nekateri faktorji so bili med seboj visoko pozitivno povezani. V tabeli 4 vidimo, da so bile najvišje korelacije med tremi faktorji notranje motivacije (segale so kar od 0,73 do 0,76 ) in med tremi faktorji zunanje motivacije (segale so od 0,50 do 0,65 ). Tudi v prejšnjih raziskavah so avtorji ugotavljali zmerne korelacije med faktorji zunanje motivacije (npr. Guay idr., 2015), visoke korelacije pa zlasti med tremi faktorji notranje motivacije (npr. Guay idr., 2015; Vallerand idr., 1989; Vallerand idr., 1993). Vendar so Carbonneau idr. (2012) s postopki ugotavljanja veljavnosti v več vzorcih ugotovili, da gre za tri diferencirane konstrukte, saj pri posameznikih prevladuje določena vrsta notranje motivacije glede na dejavnost, v kateri se udejstvuje. Posameznik se glede na to, ali pri njem prevladuje želja po védenju, obvladovanju 
Tabela 4. Korelacije med faktorji lestvice AMS-C 28

\begin{tabular}{|c|c|c|c|c|c|c|}
\hline & 1 & 2 & 3 & 4 & 5 & 6 \\
\hline \multicolumn{7}{|l|}{$1-$ Želja po védenju } \\
\hline 2 - Želja po obvladovanju &, $76^{* * *}$ & & & & & \\
\hline 3 - Želja po doživljanju stimulacije &, $76^{* * *}$ &, $73^{* * *}$ & & & & \\
\hline 4 - Identificirano uravnavanje &, $59^{* * *}$ &, $49^{* * *}$ &, $29^{* *}$ & & & \\
\hline 5 - Introjicirano uravnavanje &, $31^{* *}$ &, $68^{* * *}$ &, $32^{* *}$ &, $50^{* * *}$ & & \\
\hline 6 - Zunanje uravnavanje &, 07 & $21^{*}$ &,- 11 &, $61^{* * *}$ &, $65^{* * *}$ & \\
\hline 7 - Amotivacija &,$- 41^{* * *}$ &,- 12 &,- 02 &,$- 46^{* * *}$ &,- 05 &,- 14 \\
\hline
\end{tabular}

${ }^{*} p<, 05 ;{ }^{* *} p<, 01 ;{ }^{* * *} p<, 001$.

ali doživljanju stimulacije, usmerja k tistim dejavnostim, ki bodo njegovo potrebo zadovoljile (npr. pri igrah na srečo ima posameznik bolj izražen motiv po doživljanju stimulacije, pri pridobivanju znanja pa željo po védenju).

Korelacije med vrstami notranje motivacije so bile višje kot korelacije med vrstami notranje in vrstami zunanje motivacije, prav tako so bile korelacije med vrstami zunanje motivacije višje kot korelacije med vrstami notranje in zunanje motivacije (tabela 4). Izjema je bila le visoka pozitivna korelacija med faktorjem notranje motivacije Željo po obvladovanju in faktorjem zunanje motivacije Introjiciranim uravnavanjem $(0,68)$. Tako sva predpostavko o višjih korelacijah znotraj vrst zunanje ali notranje motivacije kot med njima potrdili, z izjemo zgoraj omenjene korelacije. Visoka korelacija med Željo po obvladovanju in Introjiciranim uravnavanjem je razumljiva, saj oba faktorja vključujeta postavke o preseganju samega sebe in uspešnosti, pri čemer postavke na faktorju Želja po obvladovanju vključujejo tudi osebno zadovoljstvo ob uspehu, postavke na faktorju Introjicirano uravnavanje pa ne. Podobno so tudi v preteklih raziskavah avtorji ugotavljali, da se v izobraževalnem (storilnostnem) kontekstu introjicirano uravnavanje v večji meri povezuje z željo po obvladovanju kot v ostalih življenjskih kontekstih (npr. Carbonneau idr., 2012), prav tako pa se pozitivno povezuje s pokazatelji dobre učne (študijske) prilagojenosti (npr. Blanchard idr., 1997; Fairchild idr., 2005; Guay idr., 2015).

Tudi nizke do zmerno visoke pozitivne korelacije med faktorji notranje motivacije in faktorjem Identificirano uravnavanje (tabela 4) opozarjajo, da delitev faktorjev na tiste, ki odražajo notranjo motivacijo, in tiste, ki odražajo zunanjo, ni enoznačna. Ryan in Deci (2000b), denimo, obravnavata identificirano uravnavanje kot precej samodoločujočo obliko zunanje motivacije, saj pri tej vrsti motivacije posameznik prepoznava neko dejavnost, kljub njeni instrumentalni naravi, kot osebno vredno in se zato $\mathrm{z}$ njo tudi identificira (tj. ponotranji neko dejavnost in njene regulacije, saj ga ta vodi $\mathrm{k}$ osebnemu cilju).

Dosežek na faktorju Amotivacija je bil zmerno negativno povezan $\mathrm{z}$ dosežkom na faktorjih Želja po védenju in Identificirano uravnavanje (glej tabelo 4), s čimer sva potrdili najino predpostavko. Študenti, ki so bili bolj nemotivirani za študij, so bili manj željni znanja in manj prepričani, da jih bo študij usposobil za bodoči poklic.

Pregledali sva, kakšne so bile razlike med spoloma v posameznih latentnih spremenljivkah. V skalarnem modelu 2, računanem s standardiziranimi vrednostmi spremenljivk,

Tabela 5. Korelacije med dosežki na motivacijskih faktorjih AMS-C 28, dosežki na faktorjih lestvice poklicnih ciljev CGS in prepričanostjo o ustreznosti izbranega študija

\begin{tabular}{|c|c|c|c|c|}
\hline Lestvica AMS-C 28 & $\begin{array}{l}\text { Prepričanost } \\
\text { pred }\end{array}$ & $\begin{array}{l}\text { Trenutna } \\
\text { prepričanost }\end{array}$ & $\begin{array}{l}\text { CGS } \\
\text { Ekstrinzični cilji }\end{array}$ & $\begin{array}{l}\text { CGS } \\
\text { Intrinzični cilji }\end{array}$ \\
\hline \multicolumn{5}{|l|}{ Študenti $(n=148)$} \\
\hline Želja po védenju & ,12 &, $33^{* *}$ &,- 04 &, $79^{* * *}$ \\
\hline Želja po obvladovanju &, 15 &, 15 &, $28^{*}$ &, $55^{* * *}$ \\
\hline Želja po doživljanju stimulacije & 10 &, 12 & 03 &, $49^{* * *}$ \\
\hline Identificirano uravnavanje &, 16 &, $34^{* *}$ & $26^{*}$ &, $50^{* * *}$ \\
\hline Introjicirano uravnavanje &, 01 &, 07 &, $43^{* * *}$ &, $22^{*}$ \\
\hline Zunanje uravnavanje &,- 11 &, 11 &, $42^{* * *}$ &, 14 \\
\hline Amotivacija &,$- 21^{*}$ &,$- 55^{* * *}$ &, 13 &,$- 35^{* * *}$ \\
\hline \multicolumn{5}{|l|}{ Študentke $(n=165)$} \\
\hline Želja po védenju &, 05 &, $25^{*}$ & ,08 &, $66^{* * *}$ \\
\hline Želja po obvladovanju & 01 &, 16 & $29^{* *}$ &, $58^{* * *}$ \\
\hline Želja po doživljanju stimulacije &, 04 &, $20^{*}$ &, 11 &, $62^{* * *}$ \\
\hline Identificirano uravnavanje &, $23^{*}$ & ,20* &, $28^{*}$ &, $25^{*}$ \\
\hline Introjicirano uravnavanje & ,12 &,- 11 &, $48^{* * *}$ &, 11 \\
\hline Zunanje uravnavanje &, 13 &, 02 &, $63^{* * *}$ & ,02 \\
\hline Amotivacija &,- 13 &,$- 56^{* * *}$ &, 03 &,$- 34^{* *}$ \\
\hline
\end{tabular}

${ }^{*} p<, 05 ;{ }^{* *} p<, 01 ;{ }^{* * *} p<, 001$. 
Tabela 6. Opisne statistike dosežkov na sedmih lestvicah AMS-C 28, računanih v obliki povprečnih odgovorov na postavke $(N=324)$

\begin{tabular}{|c|c|c|c|c|c|c|c|c|c|}
\hline Lestvica & $M$ & $S D$ & $\gamma_{1}$ & $\gamma_{2}$ & $P_{5}$ & $P_{25}$ & $P_{50}$ & $P_{75}$ & $P_{95}$ \\
\hline Želja po védenju & 5,31 & 1,19 & $-0,56$ & $-0,31$ & 3,0 & 4,5 & 5,4 & 6,2 & 7,0 \\
\hline \multicolumn{10}{|l|}{ Želja po obvladovanju } \\
\hline Moški & 4,28 & 1,48 & $-0,10$ & $-0,51$ & 1,8 & 3,2 & 4,3 & 5,3 & 6,9 \\
\hline Ženske & 4,62 & 1,42 & $-0,43$ & $-0,27$ & 1,9 & 3,8 & 4,7 & 5,7 & 6,8 \\
\hline Želja po doživljanju stimulacije & 4,19 & 1,35 & $-0,04$ & $-0,57$ & 1,9 & 3,2 & 4,2 & 5,1 & 6,5 \\
\hline \multicolumn{10}{|l|}{ Identificirano uravnavanje } \\
\hline Moški & 5,26 & 1,18 & $-0,90$ & 1,08 & 3,0 & 4,6 & 5,4 & 6,1 & 6,9 \\
\hline Ženske & 5,61 & 1,08 & $-1,13$ & 1,48 & 3,7 & 5,1 & 5,8 & 6,4 & 6,4 \\
\hline \multicolumn{10}{|l|}{ Introjicirano uravnavanje } \\
\hline Moški & 4,34 & 1,56 & $-0,37$ & $-0,65$ & 1,3 & 3,2 & 4,5 & 5,6 & 6,7 \\
\hline Ženske & 4,77 & 1,55 & $-0,43$ & $-0,70$ & 1,9 & 3,6 & 4,9 & 6,1 & 7,0 \\
\hline Zunanje uravnavanje & 5,21 & 1,36 & $-0,87$ & 0,27 & 2,4 & 4,5 & 5,5 & 6,2 & 7,0 \\
\hline Amotivacija & 2,24 & 1,36 & 1,15 & 0,50 & 1,0 & 1,2 & 1,7 & 3,0 & 5,0 \\
\hline
\end{tabular}

Opombe: Oznaka $\gamma_{1}$ predstavlja Pearsonov koeficient asimetrije, standardna napaka zanj je znašala 0,14. Oznaka $\gamma_{2}$ predstavlja Pearsonov koeficient presežka sploščenosti, standardna napaka zanj je znašala 0,27 . Pri določanju percentilnih vrednosti je bila odgovorna lestvica obravnavana kot zvezen kontinuum, na katerem so vrednosti zaokrožene na cela števila, ki predstavljajo interval vrednosti.

so bila povprečja večine faktorjev pri ženskah višja od referenčnih povprečij faktorjev pri moških (ki jim je bila določena vrednost 0), edino pri faktorju Amotivacija je bilo povprečje nižje kot pri moških. Pri faktorju Želja po védenju je bilo povprečje faktorja pri ženskah višje za 0,17 , pri faktorju Želja po obvladovanju za 0,34 , pri faktorju Želja po doživljanju stimulacije za 0,13 , pri faktorju Identificirano uravnavanje za 0,44 , pri faktorju Introjicirano uravnavanje za 0,31 , pri faktorju Zunanje uravnavanje za 0,06 , pri faktorju Amotivacija pa je bilo povprečje pri študentkah za 0,22 nižje od povprečja pri študentih.

Skalarni model 2, v katerem sva ocenjevali povprečja latentnih spremenljivk, sva primerjali z različnimi modeli, v katerih sva povprečja latentnih spremenljivk izenačili med spoloma. Najprej sva skalarni model 2 primerjali $\mathrm{z}$ modelom, $\mathrm{v}$ katerem sva izenačili povprečja vseh faktorjev (hipoteza 0). Na ta način sva želeli ugotoviti, ali se spola na splošno statistično značilno razlikujeta $v$ izraženosti sedmih motivacijskih faktorjev. Nato sva skalarni model 2 primerjali še z modeli, v katerih sva izenačili povprečja posameznih od sedmih faktorjev (pri preverjanju hipoteze 1 le povprečje faktorja 1, pri preverjanju hipoteze 2 le povprečje faktorja 2 , itd.), da bi ugotovili, ali se spola razlikujeta v izraženosti posameznega motivacijskega faktorja. Rezultati posameznih primerjav modelov so prikazani v spodnjem delu tabele 2 . Študenti in študentke so se na splošno statistično značilno razlikovali v izraženosti motivacijskih faktorjev (hipoteza 0); model, v katerem sva izenačili povprečja vseh faktorjev pri obeh spolih, je statistično značilno slabše pojasnjeval dejansko kovariančno matriko kot model, ki je predvideval različno izražene faktorje pri obeh spolih. V zvezi z razlikami med spoloma $\mathrm{v}$ izraženosti posameznih motivacijskih faktorjev sva med spoloma, tako kot sva pričakovali na osnovi literature (Guay idr., 2015; Vallerand idr., 1989, 1992), našli statistično značilne razlike $\mathrm{v}$ dosežkih na lestvicah Želja po obvladovanju, Identificirano uravnavanje in Introjicirano uravnavanje, medtem ko razlike pri drugih faktorjih niso dosegle statistične značilnosti (glej tabelo 2). Pri lestvicah, kjer so razlike med spoloma dosegle statistično značilnost, lahko (glede na to, da so velikosti razlik izražene $v$ enotah standardne deviacije faktorskega dosežka in torej lahko o njih presojamo kot o Cohenovem $d$ ) razlike označimo za majhne. Študente torej nekoliko manj kot študentke vodi pri študiju želja po obvladovanju, samonadzor $\mathrm{v}$ obliki notranjega pritiska (npr. dokazati sebi, da zmorem) in notranjih nagrad (npr. doživljanje ponosa ob opravljeni nalogi), manj pa se tudi identificirajo s študijskimi dejavnostmi, da bi tako izpolnili svoje osebne cilje. Pri tem je treba omeniti, da so bile povprečne vrednosti vidikov notranje motivacije za študij pri študentih (ne glede na spol) izražene nad povprečno oceno 4 (zlasti želja po védenju), vendar je bilo dokaj visoko izraženo tudi zunanje uravnavanje. V povprečju so se torej študentje precej strinjali, da so razlogi za njihov študij predvsem $\mathrm{v}$ iskanju dobro plačane in ugledne službe in želji po dobrem življenju.

Dosežke na različnih faktorjih sva korelirali s trenutno prepričanostjo študentov, da je njihov izbrani študij prava izbira, $\mathrm{z}$ oceno te prepričanosti pred začetkom študija in s faktorskimi dosežki na lestvicah intrinzičnih in ekstrinzičnih poklicnih ciljev. Korelacije so prikazane v tabeli 5 ločeno za oba spola. Trenutna, pri študentkah pa tudi pretekla prepričanost o ustreznosti izbire študija je bila pri obeh spolih najvišje (tj., nizko do zmerno) pozitivno povezana $\mathrm{z}$ dosežkom na lestvici Identificirano uravnavanje, nista pa se povezovali z drugimi lestvicami zunanje motivacije. Trenutna prepričanost se je nizko in pozitivno povezovala $\mathrm{z}$ dosežkom na lestvici Želja po védenju. Trenutna prepričanost o ustreznosti izbire študija se je pri študentkah pozitivno, a nizko povezovala še $\mathrm{z}$ dosežkom na lestvici Želja po doživljanju stimulacije. Posameznikova (zlasti trenutna) prepričanost, da je pravilno izbral študij, se torej pričakovano povezuje $\mathrm{z}$ notranjo motivacijo za študij ter z najbolj samodoločujočo obliko zunanje motivacije, ki jo meri AMS, v največji meri pa je (negativno) povezana 
$\mathrm{z}$ odsotnostjo namer za študij in neudejstvovanjem ali mehaničnim udejstvovanjem pri študiju (tj. $\mathrm{z}$ amotivacijo). Dosežek na lestvici Ekstrinzični cilji se je nizko do visoko pozitivno povezoval $\mathrm{z}$ dosežkom na treh lestvicah zunanje motivacije in lestvici Želja po obvladovanju. Skladno s predhodno ugotovitvijo, da se dosežek na slednji povezuje tudi z dosežki na lestvicah zunanje motivacije na AMS-C 28, bi torej lahko rekli, da lestvica Želja po obvladovanju vsebinsko ne odraža le popolno samodoločujoče notranje motivacije, kar je razumljivo, saj opisuje samodokazovanje posameznika v učnem kontekstu, ki je storilnostno usmerjen (tj. zahteva dosežek). Študentom, ki se radi samodokazujejo pri študiju in pri tem doživljajo osebno zadovoljstvo, kot kaže, niso pomembni le intrinzični poklicni cilji (nadaljevati $\mathrm{z}$ učenjem in izpopolnjevanjem, imeti zanimivo delo, polno izzivov, prispevati s svojim delom k družbi), ampak na poklicni poti pričakujejo tudi ekstrinzične pobude (finančni uspeh, visok družbeni položaj, vplivnost v delovnem okolju). Dosežek na lestvici Intrinzični cilji se je pričakovano negativno povezoval z dosežkom na lestvici Amotivacija in visoko pozitivno $z$ dosežki na vseh ostalih lestvicah AMS-C 28 , razen na lestvici Zunanje uravnavanje in pri študentkah tudi na lestvici Introjicirano uravnavanje. Če povzamemo, smer in višina korelacij med prepričanostjo o ustreznosti izbire študija in dosežki na lestvicah poklicnih ciljev na eni strani ter dosežki na lestvicah akademske motivacije na drugi strani sta bili smiselni in kažeta na ustrezno konvergentno veljavnost lestvice AMS-C 28.

Ker za AMS-C drži delna skalarna invariantnost (in bi bilo potrebno upoštevati različnost presečišč za študentke in študente samo na eni od postavk) in so nasičenosti postavk s posameznim faktorjem razmeroma podobne, sva za izdelavo orientacijskih norm dosežek na posamezni podlestvici določili na običajen in enostaven način, tj. kot povprečni odgovor na postavke, ki spadajo k posameznemu faktorju. V tabeli 6 so prikazane osnovne opisne statistike tako dobljenih dosežkov na posameznih lestvicah, ločeno za spola tam, kjer so bile razlike med spoloma $\mathrm{v}$ faktorskem dosežku statistično značilne, in združeno pri ostalih lestvicah. Dosežki se povečini ne porazdeljujejo normalno, zato bi bilo kot orientacijske norme bolje uporabiti percentilne vrednosti.

\section{Zaključek}

V študiji sva ugotavljali konstruktno in konvergentno veljavnost ter notranjo zanesljivost Lestvice akademske motivacije AMS-C 28 na vzorcu slovenskih študentov. Kljub multidimenzionalnemu značaju lestvice (sestavlja jo 7 motivacijskih lestvic) in visokim korelacijam zlasti med vrstami notranje motivacije, ugotavljava sprejemljivo prileganje originalne 7-faktorske strukture slovenskim podatkom. Prav tako ugotavljava dobro konvergentno veljavnost lestvice ter delno skalarno invariantnost glede na spol.

Korelacije med vrstami notranje motivacije so višje kot korelacije med vrstami notranje in vrstami zunanje motivacije. Prav tako so korelacije med vrstami zunanje motivacije (zunanje in introjicirano uravnavanje) povečini višje kot njihove korelacije $\mathrm{z}$ vrstami notranje motivacije.
Notranja motivacija za študij je negativno povezana $\mathrm{Z}$ amotivacijo. Vrste akademske motivacije se tudi smiselno povezujejo z ekstrinzičnimi in intrinzičnimi poklicnimi cilji ter s prepričanostjo $v$ pravo izbiro svojega študija. Notranja zanesljivostvseh sedmihlestvicje dobra. Študentje inštudentke se statistično značilno razlikujejo v želji po obvladovanju ter introjiciranem in identificiranem uravnavanju, vendar razlike lahko označimo za majhne.

Uporabnost lestvice vidiva predvsem $\mathrm{v}$ procesu kariernega svetovanja kot merski pripomoček ugotavljanja vrste motivacije za študij nekega področja ter identifikacije psiholoških težav, s katerimi se študent sooča tekom študija in so povezane $\mathrm{z}$ njegovo študijsko motivacijo. Z ugotovitvijo namer za študij pri študentih lahko visokošolski učitelji bolje oblikujemo učni kontekst, v katerem bodo študentje lažje zadovoljevali svoje študijske potrebe. Lestvica je uporabna tudi v znanstvene namene ugotavljanja motivacije za študij kot enega od elementov akademske prilagojenosti.

\section{Literatura}

Blanchard, S., Vrignaud, P., Lallemand, N., Dosnon, O. in Wach, M. (1997). Validation de l'echelle de motivation en éducation auprès de lycéens Français [Validation of the Academic Motivation Scale among high school students]. L'Orientation Scolaire et Professionnelle, 26, 33-56.

Carbonneau, N., Vallerand, R. J. in Lafrenière, M.-A. K. (2012). Toward a tripartite model of intrinsic motivation. Journal of Personality, 80, 1147-1177.

Cokley, K. O., Bernard, N., Cunningham, D in Motoike, J. (2001). A psychometric investigation of the academic motivation scale using a United States sample. Measurement and Evaluation in Counseling and Development, 34, 109-119.

Deci, E. L. (1975). Intrinsic motivation. New York, NY, ZDA: Plenum.

Deci, E. L. in Ryan, R. M. (1985). Intrinsic motivation and self-determination in human behavior. New York, NY, ZDA: Plenum.

Deci, E. L. in Ryan, R. M. (2002). The paradox of achievement: The harder you push, the worse it gets. V J. Aronson (ur.), Improving academic achievement (str. 61-87). Amsterdam, Nizozemska: Academic Press.

Fairchild, A. J., Horsta, S. J., Finneya, S. J. in Barron, K. E. (2005). Evaluating existing and new validity evidence for the Academic Motivation Scale. Contemporary Educational Psychology, 30, 331-358.

Guay, F., Morin, A. J. S., Litalien, D., Valois, P. in Vallerand, R. J. (2015). Application of exploratory structural equation modeling to evaluate the Academic Motivation Scale. The Journal of Experimental Education, 83, 51-82.

Harter, S. (1981). A new self-report scale of intrinsic vs. extrinsic orientation in the classroom: Motivational and informational components. Developmental Psychology, 17, 300-312.

Hooper, D., Coughlan, J. in Mullen, M. R. (2008). Structural equation modelling: Guidelines for determining model fit. The Electronic Journal of Business Research Methods, 6(1), 53-60. 
Hu, L. in Bentler, P. M. (1999). Cutoff criteria for fit indexes in covariance structure analysis: Conventional criteria versus new alternatives. Structural Equation Modeling: A multidisciplinary Journal, 6(1), 1-55.

Muthén, L. K. in Muthén, B. O. (1998-2010). Mplus user's guide (6. izd.). Los Angeles, CA, ZDA: Muthén \& Muthén.

Puklek Levpušček, M., Rauch, V. in Komidar, L. (v recenziji). Individuation in relationship to parents as a predictor of career goals and career optimism in university students. Scandinavian Journal of Psychology.

Revelle, W. (b. d.). Alternative estimates of test reliability [R documentation]. Dosegljivo na: http://personality-project. org $/ \mathrm{r} / \mathrm{html} /$ guttman.html

Ryan, R. M. in Deci, E. L. (2000a). Self-determination theory and the facilitation of intrinsic motivation, social development and well-being. American Psychologist, 55, 68-78.

Ryan, R. M. in Deci, E. L. (2000b). Intrinsic and extrinsic motivation: Classic definitions and new directions. Contemporary Educational Psychology, 25, 54-67.

Seibert, S. E., Kraimer, M. L., Holtom, B. C. in Pierotti, A. J. (2013). Even the best laid plans sometimes go askew: Career self-management processes, career shocks, and the decision to pursue graduate education. Journal of Applied Psychology, 98(1), 169-182.

Ten Berge, J. M. F. in Sočan, G. (2004). The greatest lower bound to the reliability of a test and the hypothesis of unidimensionality. Psychometrika, 69(4), 613-625.

Vallerand, R. J., Blais, M. R., Brière, N. M. in Pelletier, L. G. (1989). Construction et validation de l'Échelle de Motivation en Éducation [Construction and validation of The Academic Motivation Scale]. Revue Canadienne des Sciences du Comportement, 21, 323-349.

Vallerand, R. J., Pelletier, L. G., Blais, M. R., Brière, N. M., Senécal, C. B. in Vallières, E. F. (1992). The Academic Motivation Scale: A measure of intrinsic, extrinsic, and amotivation in education. Educational and Psychological Measurement, 52, 1003-1017.

Vallerand, R. J., Pelletier, L. G., Blais, M. R., Brière, N. M., Senécal, C. B. in Vallières, E. F. (1993). On the assessment of intrinsic, extrinsic, and amotivation in education: Evidence on the concurrent and construct validity of the Academic Motivation Scale. Educational and Psychological Measurement, 53, 159-172. 